\title{
Traces of the bone-eating annelid Osedax in Oligocene whale teeth and fish bones
}

\author{
Steffen Kiel · Wolf-Achim Kahl · James L. Goedert
}

Received: 17 August 2012/ Accepted: 12 November 2012/Published online: 7 December 2012

(C) The Author(s) 2012. This article is published with open access at Springerlink.com

\begin{abstract}
The range of substrates that the bone-eating marine worm Osedax is able to consume has important implications for its evolutionary history, especially its potential link to the rise of whales. Once considered a whale specialist, recent work indicates that Osedax consumes a wide range of vertebrate remains, including whale soft tissue and the bones of mammals, birds and fishes. Traces resembling those produced by living Osedax have now been recognized for the first time in Oligocene whale teeth and fish bones from deep-water strata of the Makah, Pysht and Lincoln Creek formations in western Washington State, USA. The specimens were acid etched from concretions, and details of the borehole morphology were investigated using micro-computed tomography. Together with previously published Osedax traces from this area, our results show that by Oligocene time Osedax was able to colonize the same range of vertebrate remains that it consumes today and had a similar diversity of root morphologies. This supports the view that a generalist ability to exploit vertebrate bones may be an ancestral trait of Osedax.
\end{abstract}

\footnotetext{
S. Kiel $(\bowtie)$

Geobiology Group and Courant Research Center Geobiology, University of Göttingen, Geoscience Center, Goldschmidtstr. 3, 37077 Göttingen, Germany

e-mail: skiel@uni-goettingen.de; skiel@gwdg.de

W.-A. Kahl

Fachbereich Geowissenschaften, University of Bremen,

Klagenfurter Straße (GEO), 28359 Bremen, Germany

e-mail: wakahl@uni-bremen.de

J. L. Goedert

Burke Museum, University of Washington, Box 353010, Seattle, WA 98195-3010, USA

e-mail: jgoedert@u.washington.edu
}

Keywords Deep-sea $\cdot$ Trace fossil $\cdot$ Osedax . Whale . Fish $\cdot$ Micro-CT

Kurzfassung Um die Evolutionsgeschichte des marinen, knochenfressenden Wurms Osedax zu verstehen, ist es wichtig zu wissen, zu welchen Tiergruppen die Knochen gehören, die er fressen kann. Ursprünglich wurde Osedax als Wal-Spezialist angesehen, weitere Untersuchungen zeigten jedoch, dass er ein breites Spektrum an Wirbeltierresten, inklusive Weichteile von Walen und Knochen von Vögeln und Fischen, konsumiert. Hier werden zum ersten Mal Bohrspuren in Walzähnen und Fischknochen aus oligozänen Tiefwasserablagerungen der Makah, Pysht und Lincoln Creek Formationen im Westen des US-Bundesstaates Washington dokumentiert, die solchen des rezenten Osedax stark ähneln. Die Fossilien wurden mittels verdünnter Säure aus kalkigen Konkretionen herausgelöst und die Bohrspuren wurden Computer-tomographisch untersucht. Diese und bereits bekannte Bohrspuren von Osedax aus dem westlichen Washington zeigen, dass Osedax schon im Oligozän die gleiche Bandbreite von Wirbeltierresten besiedelt hat wie heute und auch die gleiche Vielfalt an Weichkörpermorphologien. Diese Ergebnisse stützen die These, dass ein breites Nahrungsspektrum ein ursprüngliches Merkmal von Osedax ist.

Schlüsselworte Tiefsee $\cdot$ Spurenfossil - Osedax Wal · Fisch · Micro-CT

\section{Introduction}

Species of Osedax are marine annelids with the ability to exploit bones on the seafloor for nutrition, presumably by living in symbiosis with collagenolytic bacteria (Rouse 
et al. 2004; Goffredi et al. 2005). The range of substrates that Osedax is able to exploit has been the matter of a controversial debate (Glover et al. 2008; Jones et al. 2008; Vrijenhoek et al. 2008; Rouse et al. 2011) because it has an important implications for its origin, diversification and dispersal. Most Osedax species were first found on whale bones, and initial molecular clock estimates for the evolutionary age of Osedax pointed to an Eocene origin, coincident with the rise of whales (Rouse et al. 2004). This result was supported by fossil evidence for Osedax in Oligocene whale bones (Kiel et al. 2010). There is growing evidence, however, that Osedax can colonize other substrates as well, including spermaceti, soft tissue and blubber of whales (Fujikura et al. 2006; Fujiwara et al. 2007), cow bones (Jones et al. 2008), bird bones (Kiel et al. 2011) and fish bones (Rouse et al. 2011), leading Rouse et al. (2011) to conclude that a generalist ability to exploit vertebrate bones may be an ancestral trait of Osedax. This is important in light of more recent molecular age estimates for Osedax, indicating that a Cretaceous origin might be possible (Vrijenhoek et al. 2009), which requires that Osedax had to have the ability to consume substrates other than whale bones, at least early in its evolutionary history. Here we document traces of Osedax in fossil whale teeth and fish bones from Oligocene deep-water sediments in western Washington State, USA (Fig. 1). Together with previously reported Osedax traces in Oligocene whale and bird bones from this area (Kiel et al. 2010, 2011), our findings show that by the Oligocene time Osedax was able to consume the same range of substrates that it consumes today.

\section{Institutional abbreviations}

GZG: Geoscience Museum, University of Göttingen, Germany. LACM: Natural History Museum of Los Angeles County, Invertebrate (IP) and Vertebrate (VP) Paleontology sections, Los Angeles, CA, USA. USNM: Smithsonian Natural History Museum, Washington, D.C., USA. UWBM: University of Washington, Burke Museum, Seattle, WA, USA.

\section{Materials and methods}

Fish bones

Fish bones and scales (GZG.V.20407) are from a concretion found as a float on the beach terrace approximately $850 \mathrm{~m}$ northwest of the mouth of Sekiu River in Clallam County, Washington State, USA, in the presumably late Oligocene part of the Makah Formation. The locality is at $48^{\circ} 17.645^{\prime} \mathrm{N}, 124^{\circ} 24.296^{\prime} \mathrm{W}$, and near the southern

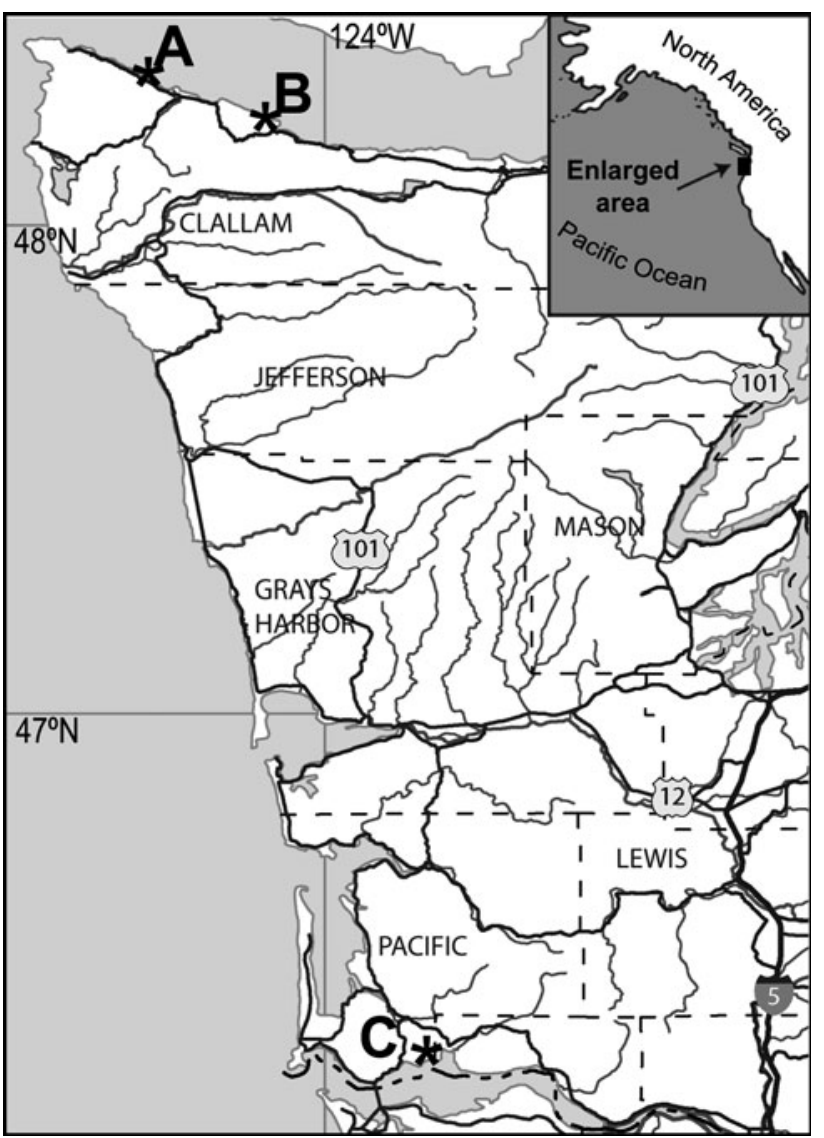

Fig. 1 Fossil locality map. A Sekiu River (UWBM loc. C1660). $B$ Murdock Creek (LACMVP loc. 5412). $C$ Knappton (LACMVP loc. 4510)

boundary of Section 5, T32 N, R13 W, Sekiu River, Washington quadrangle (USGS), $7.5 \mathrm{~min}$ series, 1984 provisional edition; this is UWBM loc. C1660. The bones are very brittle and locally silicified; the fragment used for micro-CT scanning was not silicified. Bones and scales were etched from the concretion using dilute (ca. 5-10 \%) formic acid. The scales suggest that the fish was a deep-sea aulopiform, protacanthopterygian or scambroid. Foraminiferans and sedimentary characteristics indicate deposition of the Makah Formation in open-marine conditions at lower to middle bathyal depths (Snavely et al. 1980).

Whale teeth

A jaw fragment including several teeth (GZG.V.20408), possibly from a small, toothed mysticete whale, was collected in a concretion on the North shore of the Columbia River, Pacific County, Washington State, USA, in the northern part of the bay between Grays Point and Knappton, in the latest Oligocene (Prothero et al. 2008) part of the Lincoln Creek Formation. The locality is in Section 9, T9 N, R9 W, Knappton quadrangle (USGS), 7.5 min 
series, 1949 (photo revised 1984), Pacific County, Washington; this is LACMVP locality 4510. The sediments in this area were deposited in water depths between 300 and $900 \mathrm{~m}$ based on benthic foraminifera; estimates based on mollusk and fish assemblages give slightly shallower depths (Moore 1984; Kiel 2010). Bones and teeth were etched from the concretion using dilute (5-10\%) formic acid; two teeth were used for micro-CT analysis.

Further whale teeth are from a small, toothed mysticete (USNM 539938) from the late early Oligocene part of the Pysht Formation. We have previously reported Osedax borings from a rib fragment and other bones of this specimen (Kiel et al. 2010). It was collected on the beach terrace east of Murdock Creek in Clallam County, Washington State, USA (LACMVP loc. 5412 and LACMIP loc. 6295), from deepwater sediments that are well-known for their vertebrate fossils, mostly whales (Goedert et al. 1995; Barnes and Goedert 2001) but also including bird fossils with Osedax borings (Kiel et al. 2011). The exact age of this part of the Pysht Formation has been difficult to establish (Squires and Goedert 1994; Barnes and Goedert 2001; Prothero 2001), and recently Nesbitt et al. (2010), citing local and regional problems with the biostratigraphy and magnetostratigraphy, have shown it simply as Oligocene.

Another cetacean specimen (UWBM 95841) in which the teeth show boreholes is from the late Oligocene part of the Makah Formation, from the same area as the fish bones described herein (UWBM loc. C1660). It consists of a fragment of a nodule with a skull fragment and either a fragment of dentary or maxilla, or both, and at least six teeth. It is possibly part of a toothed mysticete, and the roots of two of the teeth show the same curve and posterior extension as the tooth from USNM 539938 in Fig. 2c, but to a greater degree.

\section{Micro-CT}

The X-ray micro-computed tomography scans of the fish bone fragment (GZG.V.20407) and the two whale teeth (GZG.V.20408) were done using the SkySkan1172 system (SkyScan, Belgium). The fossil fragments were scanned with a beam energy of $100 \mathrm{kV}$, a flux of $100 \mu \mathrm{A}$, and a copper-aluminum filter at a detector resolution of $7.45 \mu \mathrm{m}$ per pixel using a 360-degree rotation with a step size of 0.6 degrees. The scan to survey the specimen (600 transmission images) was reconstructed in a 3,124 × 3,600 matrix of 3,408 slices with a resolution of $7.45 \mu \mathrm{m}$ per voxel using the SkyScan software Nrecon running on an Intel-based Macintosh computer employing the multi-boot utility Boot Camp. The program Nrecon uses a modified Feldkamp algorithm. The segmentation of bone/tooth and boreholes was done with the SkyScan software CT Analyzer. For the study of cavity morphology details of the fish bone, a volume of interest in a $1,471 \times 1,609$ matrix of 1,851 slices was chosen. Cavities inside the whale tooth were studied in a volume of interest in a 1,524 $\times 1,998$ matrix of 2,801 slices. Visualization of the 3D models was done by the SkyScan software CTvol.
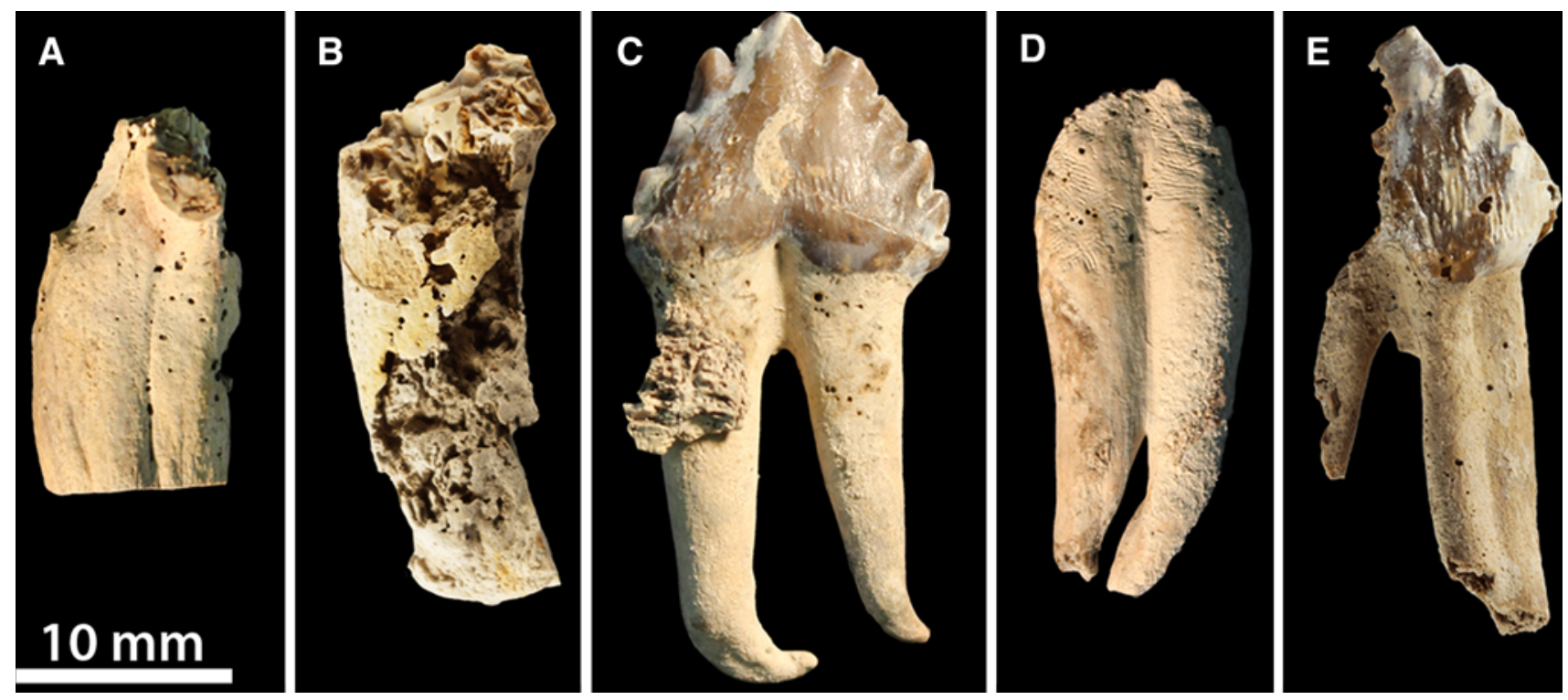

Fig. 2 Teeth of two mysticete whales with Osedax borings, Oligocene, Washington State, USA. a, b Two teeth (GZG.V.20408) from the latest Oligocene part of the Lincoln Creek Formation. These were used for micro-CT; renderings in fig. 3 are from specimen A. c-e Three teeth (USNM 539938) from the late early Oligocene part of the Pysht Formation. Note that Osedax borings are restricted to the upper (presumably exposed) part of the teeth in $\mathbf{c}$ and $\mathbf{d}$ and that the broken edges in specimen e are angular and do not go through obvious Osedax borings 


\section{Results}

Whale teeth

The jaw fragment from LACMVP loc. 4510 near Knappton was heavily corroded before being fossilized; the associated teeth have their crowns corroded away, and also the roots show strong traces of corrosion (Fig. 2a, b). Boreholes are mostly circular with sharp edges, have diameters up to $0.5 \mathrm{~mm}$, although most are smaller, and are concentrated on the upper half of the teeth but are also present on the lower half. Micro-CT scans show that the boreholes penetrate the teeth to a depth of about $0.5 \mathrm{~mm}$ or more before they start to broaden or to branch in various directions; the maximum length of individual cavities is around $3 \mathrm{~mm}$ (Fig. 3). Similar boreholes were seen on the surfaces of three teeth and two tooth roots from a toothed mysticete (USNM 539938) from LACMVP loc. 5412 at Murdock Creek (Fig. 2c, d). As in the sample from Knappton, the borings are restricted to the upper half of the teeth, have sharp edges, two reach $0.5 \mathrm{~mm}$ in diameter, but most are smaller than $0.3 \mathrm{~mm}$. A few such boreholes are also seen on the crown, typically in areas that also show traces of physical abrasion (or wear), for example, at tips of the cusps of the teeth. Bones, possibly part of a toothed mysticete (UWBM 95841) from the late Oligocene part of the Makah Formation (UWBM loc. C1660), were strongly corroded before being fossilized, and the teeth that are well exposed because of weathering (additional preparation has not been done) all show some borings. In two teeth that are exposed in cross section, the entire crown has been destroyed, with borings down into the root as well.

Fish bones

The preserved surface of the micro-CT scanned fish bone fragment shows 28 holes with a diameter $>0.1 \mathrm{~mm}$ and at
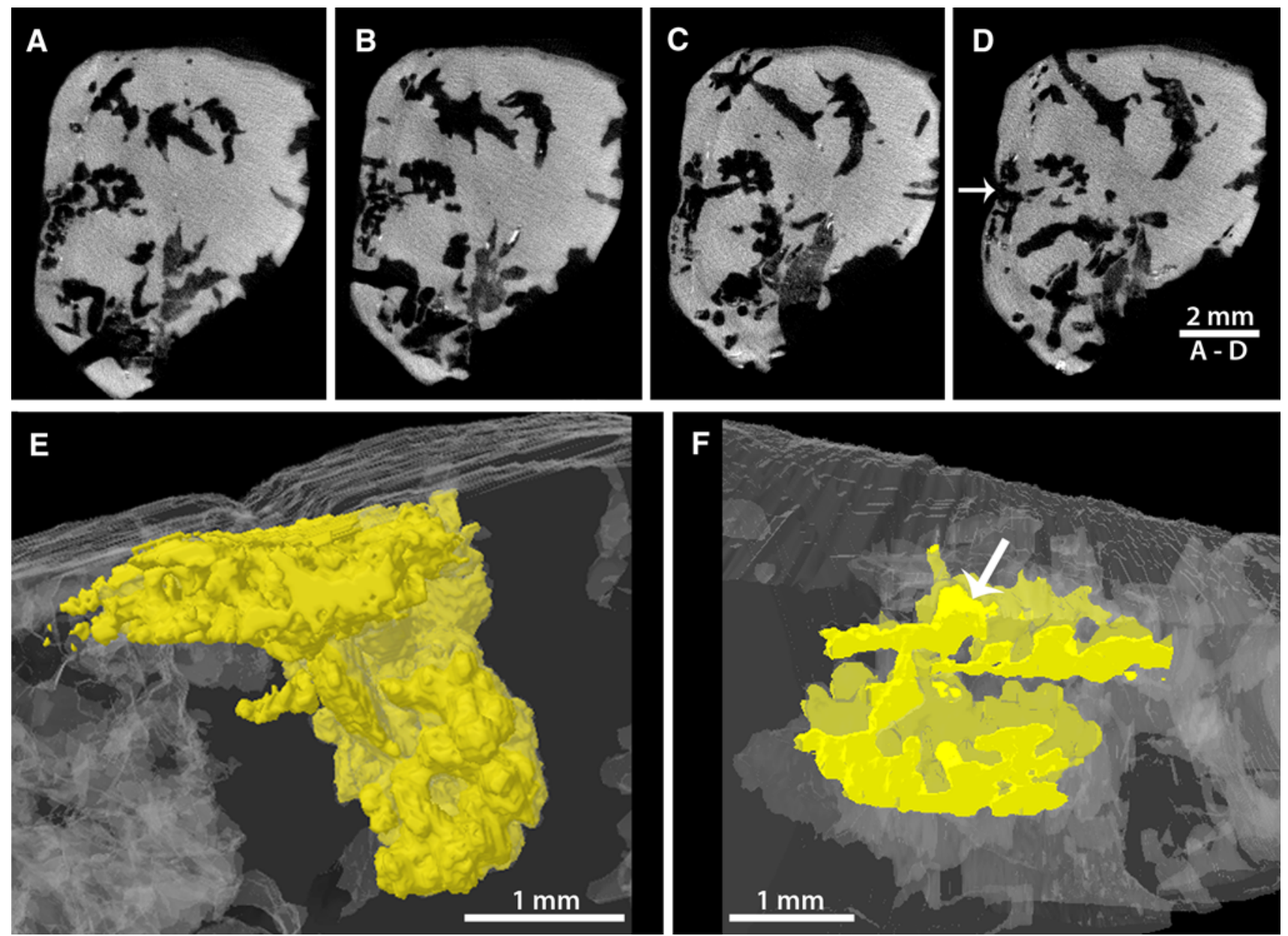

Fig. 3 Osedax borings in a tooth of a mysticete whale from the latest Oligocene part of the Lincoln Creek Formation, Washington State, USA (GZG.V.20408; same specimen as in Fig. 2a). a-d Micro-CT scan images showing cross sections with cavities and their entry holes; arrow indicating the entry hole to the boring visualized in Figs.

e and f. e, f Micro-CT-based rendering of the trace fossils indicated in Fig. d, bone material in gray, and borehole in yellow. e The complete trace fossil seen from the top (nearly the same orientation as in a-d). f Longitudinal cross section through the trace fossil 
least another 15 holes with an often considerably smaller diameter (Fig. 4). Most holes are nearly circular and have sharp edges, and the micro-CT scans show that these

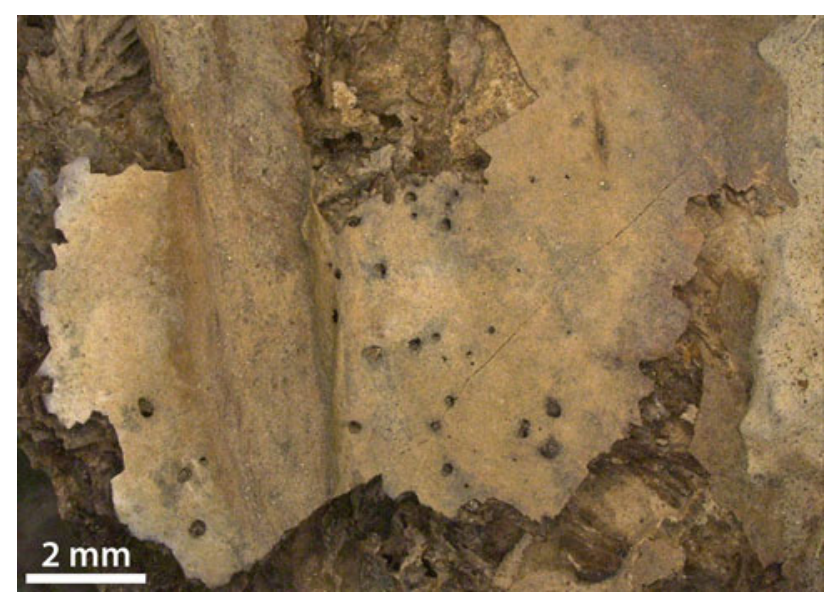

Fig. 4 Fish bone (GZG.V.20407) with Osedax borings from the presumably late Oligocene part of the Makah Formation, Washington State, USA boreholes lead through a short tunnel into cavities within the bone (Fig. 5). The cavities are of various shapes including shallow-radiating (Fig. 5), branching, or like clusters of grapes, and they are frequently, but not always, interconnected. The figured single cavity reaches a width of $6.5 \mathrm{~mm}$ and a depth of $2 \mathrm{~mm}$.

\section{Discussion}

The boreholes documented here from fossil whale teeth and fish bones are interpreted as traces of the bone-eating annelid Osedax based on their resemblance to borings made by Osedax in modern bones, to the shape of root systems of extant Osedax and to inferred Osedax traces in fossil bones. Borings produced by Osedax in modern and fossil bones typically show a short tunnel leading from a circular hole in the surface of the bone into a cavity in the interior of the bone (Fujikura et al. 2006; Kiel et al. 2010; Higgs et al. 2012); this characteristic can also be seen in the
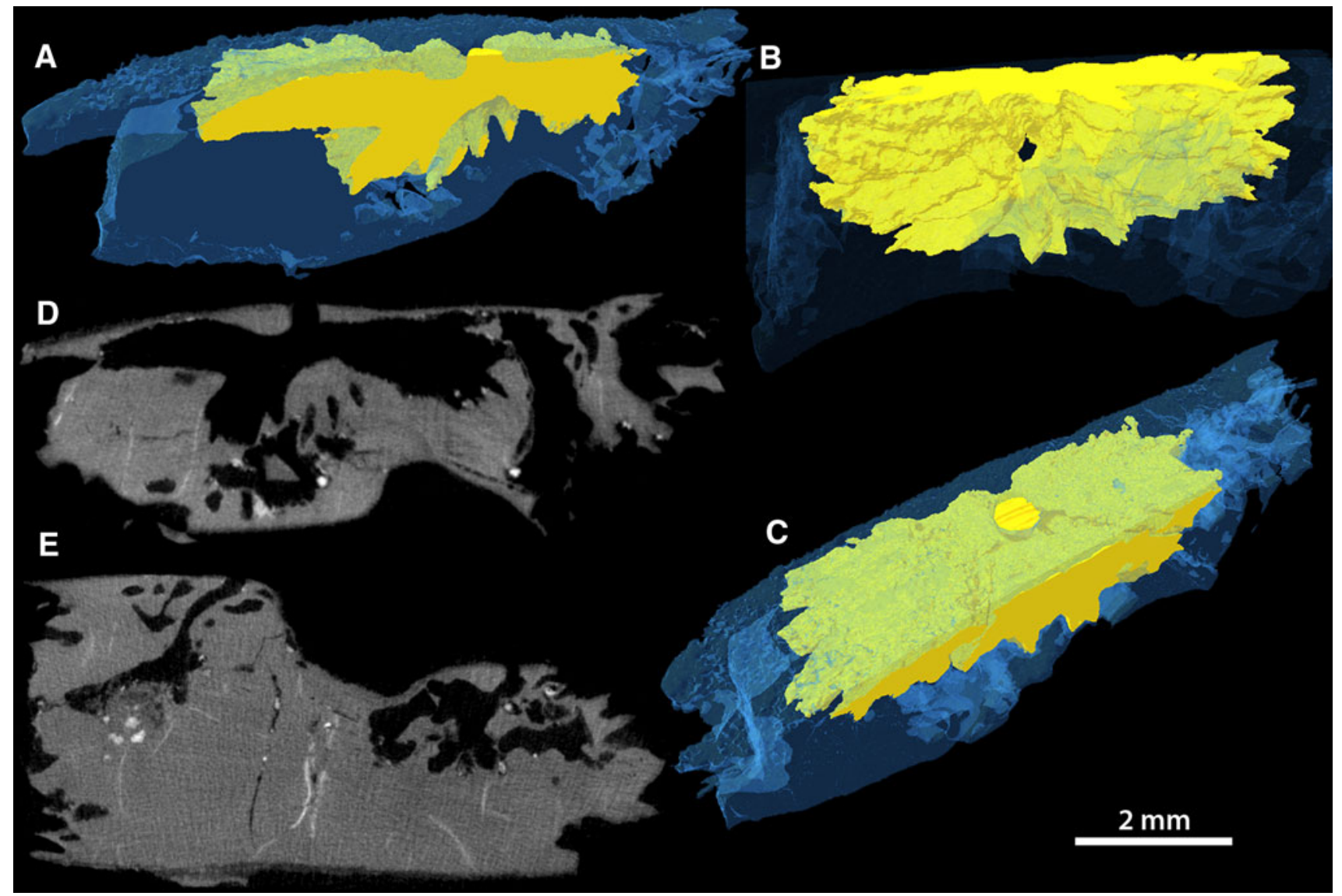

Fig. 5 Osedax borings in a fish bone from the presumably late Oligocene part of the Makah Formation, Washington State, USA (GZG.V.20407; same specimen as in fig. 4). a-c Micro-CT-based rendering of a trace fossil, bone material in transparent blue, flowerlike borehole in yellow, showing a vertical cross section including the entry hole (a), the jagged underside (b) and a top view with the circular entry hole on the bone's surface (c). d, e Micro-CT images showing the same cross section as in A (d) and a cross section with two borings including their entry holes (e) 
traces documented here. While Osedax often colonizes bones in such dense aggregations that their root systems form large cavities inhabited by many individuals, cavities with only a single borehole leading into them (single cavities) are thought to reflect the shape of the root system of an individual animal and are thus of particular diagnostic value (Kiel et al. 2010; Higgs et al. 2012). The flowershaped cavity in the fish bone is similar in shape to the root systems of extant Osedax japonicus (Fujikura et al. 2006, their fig. 3I), of Osedax roseus in a fish bone (Rouse et al. 2011, their fig. 1e), to cavities produced by Osedax mucofloris (Higgs et al. 2011, bottom of their fig. 6B) and to cavities documented from a Pliocene whale in Italy (Higgs et al. 2012, their figs. 4j, 1) interpreted as Osedax borings. However, the shape of the root system can vary significantly within species and appears to be controlled mainly by differences in bone structure (Kiel et al. 2010; Higgs et al. 2011).

Higgs et al. (2012) questioned our interpretation of boreholes in Oligocene bird bones from the Pysht Formation in Washington State as traces of Osedax (Kiel et al. 2011). Their arguments included the lack of diagnostic isolated boreholes, differing borehole sizes that were interpreted as typical for rock-boring sponges and the allegedly unusual density of boreholes of 40 holes $/ \mathrm{cm}^{2}$, which, according to Higgs et al. (2012), makes rock-boring sponges the more likely candidate for these borings. Although we did indeed find only interconnected cavities with multiple boreholes leading into them in the bird bones, this does not exclude Osedax as the boring organisms; in fact, this is the most common type of Osedax boring (Kiel et al. 2010; Higgs et al. 2011). Regarding borehole densities, we observed densities exceeding 40 holes $/ \mathrm{cm}^{2}$ on a bone of a juvenile gray whale from $633 \mathrm{~m}$ depth in Monterey Canyon, colonized by two Osedax species informally called 'orange collar' and 'yellow patch' by Vrijenhoek et al. (2009). Such high borehole densities are thus an invalid argument for reinterpretation of the borings seen in the Oligocene bird bones as sponge borings. Furthermore, mollusk shells collected at the same locality as the bored bird bones (e.g., Squires and Goedert 1994; Kiel and Goedert 2007) do not show any 'Cliona'-type borings. It seems unlikely to us that rock-boring sponges would colonize bird bones but not the co-occurring mollusk shells. Osedax, however, would certainly show such a behavior. Therefore, we maintain our view that the boreholes in the Oligocene bird bones were made by Osedax. Lastly, several Osedax species found at 1,000 m depth in Monterey Canyon colonized a turkey carcass deployed roughly $10 \mathrm{~m}$ from an existing whale-fall (R.C. Vrijenhoek, pers. comm. 2012).

Many of the whale teeth have their crowns corroded away. This may seem strange considering that they are made of hard enamel (calcium phosphate with little organic matrix), whereas the root is covered by a thin layer of softer cementum (Maas 2007) and should therefore be easier to attack. However, the enamel is very thin on these teeth, and a specimen where the crown is corroded but not totally destroyed shows that the broken edges are straight or angular, but do not go through any of the few boreholes (Fig. 2e). Damage to modern whale bones results from a combination of perforation by Osedax and crustaceans attacking Osedax (Braby et al. 2007). A similar scenario seems possible for the corroded teeth: boreholes are concentrated just underneath the crown, indicating that the teeth were attacked while still in situ. Thus, if some predator had attacked the Osedax specimens that created these holes, or Osedax specimens that had colonized the enclosing jaw bone, the thin crown could have been broken as 'collateral damage.' The common scratch marks in this area (Fig. 2d) may support this scenario. This is the first report of Osedax borings in fossil whale teeth. Living Osedax was reported from the teeth of sperm whales (suborder Odontoceti) that were sunk off the coast of Japan (Fujiwara et al. 2007; Okoshi et al. 2011) after a mass stranding event. Interestingly, in the vertebrate remains from the Oligocene strata in western Washington, we have so far not observed Osedax borings in bones or teeth positively identified as being from Odontoceti (e.g., Barnes and Goedert 2001), although this might be a coincidence.

The borings interpreted here as made by Osedax, as well as those in bones from Oligocene deep-water sediments in western Washington previously reported by us (Kiel et al. 2010, 2011), exhibit a wide variety of shapes, including radiating and flower-like, grape-like and irregular-branching, and they frequently merge to form large cavities with multiple entry holes. This diversity of shapes does not necessarily imply species diversity, but shows that the morphological diversity seen in the root systems of extant Osedax (e.g., Vrijenhoek et al. 2009) was already developed by the Oligocene time. Similarly diverse as the shape of the root system of Osedax is the range of substrates that it was able to colonize by the Oligocene: whale bones and teeth, and fish and bird bones. To summarize, fossil Osedax traces in western Washington have now been documented from a wide range of substrates spanning that of extant Osedax, with a diversity of inferred root morphologies similar to that of living Osedax, and from three different rock units with a stratigraphic age spanning most of the Oligocene. This shows that Osedax was well established in the northeastern Pacific Ocean by the Oligocene time and supports the view of Rouse et al. (2011) that a generalist ability to exploit vertebrate bones is an ancestral trait of Osedax. 
Acknowledgments We thank Gerhard Hundertmark and Thomas Dinter (Göttingen) for photography, Bettina Reichenbacher (Munich), Giorgio Carnevale (Torino) and Norbert Micklich (Darmstadt) for help identifying the fish remains, and Shannon Johnson and Bob Vrijenhoek (Moss Landing) for access to whale bones in their collection and for stimulating discussions. Nick Higgs (London) and Andrzej Kaim (Warsaw) are thanked for their constructive reviews that helped to improve the manuscript. Financial support was provided by the Deutsche Forschungsgemeinschaft through grant Ki802/ 6-1 to SK.

Open Access This article is distributed under the terms of the Creative Commons Attribution License which permits any use, distribution, and reproduction in any medium, provided the original author(s) and the source are credited.

\section{References}

Barnes, L.G., and J.L. Goedert. 2001. Stratigraphy and paleoecology of Oligocene and Miocene desmostylian occurrences in western Washington State, USA. Bulletin of the Ashoro Museum of Paleontology 2: 7-22

Braby, C.E., G.W. Rouse, S.B. Johnson, W.J. Jones, and R.C. Vrijenhoek. 2007. Bathymetric and temporal variation among Osedax bone worms and associated megafauna on whale-falls in Monterey Bay, California. Deep-Sea Research I 54: 1773-1791.

Fujikura, K., Y. Fujiwara, and M. Kawato. 2006. A new species of Osedax (Annelida: Siboglinidae) associated with whale carcasses off Kyushu, Japan. Zoological Science 23: 733-740.

Fujiwara, Y., M. Kawato, T. Yamamoto, T. Yamanaka, W. SatoOkoshi, C. Noda, S. Tsuchida, T. Komai, S.S. Cubelio, T. Sasaki, K. Jacobsen, K. Kubokawa, K. Fujikura, T. Maruyama, Y. Furushima, K. Okoshi, H. Miyake, M. Miyazaki, Y. Nogi, A. Yatabe, and T. Okutani. 2007. Three-year investigations into sperm whale-fall ecosystems in Japan. Marine Ecology 28: 219-232.

Glover, A.G., K.M. Kemp, C.R. Smith, and T.G. Dahlgren. 2008. On the role of bone-eating worms in the degradation of marine vertebrate remains. Proceedings of the Royal Society B 275: 1959-1961.

Goedert, J.L., R.L. Squires, and L.G. Barnes. 1995. Paleoecology of whale-fall habitats from deep-water Oligocene rocks, Olympic Peninsula, Washington State. Palaeogeography, Palaeoclimatology, Palaeoecology 118: 151-158.

Goffredi, S.K., V.J. Orphan, G.W. Rouse, L. Jahnke, T. Embaye, K. Turk, R. Lee, and R.C. Vrijenhoek. 2005. Evolutionary innovation: A bone-eating marine symbiosis. Environmental Microbiology 7: 1369-1378.

Higgs, N.D., A.G. Glover, T.G. Dahlgren, and C.T.S. Little. 2011. Bone-boring worms: Characterizing the morphology, rate, and method of bioerosion by Osedax mucofloris (Annelida, Siboglinidae). Biological Bulletin 221: 307-316.

Higgs, N.D., C.T.S. Little, A.G. Glover, T.G. Dahlgren, C.R. Smith, and S. Dominici. 2012. Evidence of Osedax worm borings in Pliocene ( $\sim 3 \mathrm{Ma})$ whale bone from the Mediterranean. Historical Biology 24: 269-277.
Jones, W.J., S.B. Johnson, G.W. Rouse, and R.C. Vrijenhoek. 2008. Marine worms (genus Osedax) colonize cow bones. Proceedings of the Royal Society B 275: 387-391.

Kiel, S. 2010. On the potential generality of depth-related ecologic structure in cold-seep communities: Cenozoic and Mesozoic examples. Palaeogeography, Palaeoclimatology, Palaeoecology 295: 245-257.

Kiel, S., and J.L. Goedert. 2007. Six new mollusk species associated with biogenic substrates in Cenozoic deep-water sediments in Washington State, USA. Acta Palaeontologica Polonica 52: 41-52.

Kiel, S., J.L. Goedert, W.-A. Kahl, and G.W. Rouse. 2010. Fossil traces of the bone-eating worm Osedax in early Oligocene whale bones. Proceedings of the National Academy of Sciences of the USA 107: 8656-8659.

Kiel, S., W.-A. Kahl, and J.L. Goedert. 2011. Osedax borings in fossil marine bird bones. Naturwissenschaften 98: 51-55.

Maas, M.C. 2007. The histology of bones and teeth. In Encyclopedia of marine mammals, 2nd ed, ed. W.F. Perrin, 124-129. Amsterdam: Elsevier.

Moore, E.J. 1984. Molluscan paleontology and biostratigraphy of the lower Miocene upper part of the Lincoln Creek formation in southwestern Washington. Contributions in Science, Natural History Museum of Los Angeles County 351: 1-42.

Nesbitt, E.A., R.A. Martin, N.P. Carroll, and J. Grieff. 2010. Reassessment of the Zemorrian foraminiferal stage and Juanian molluscan stage north of the Olympic Mountains, Washington State and Vancouver Island. Newsletters on Stratigraphy 43: 275-291.

Okoshi, K., Fujiwara, Y., and the scientific shipboard party, 2011. R/V Kaiyo+ROV Hyper-Dolphin 3000 Cruise Report, KY11-01 Leg 2 Cruise in Sagami Bay, JAMSTEC.

Prothero, D.R., 2001 Chronostratigraphic calibrations of the Pacific Coast Cenozoic: A summary. In Magnetic stratigraphy of the Pacific coast Cenozoic, ed. Prothero D.R., 377-394. The Pacific Section SEPM.

Prothero, D.R., J.M. Hoffman, and J.L. Goedert. 2008. Paleomagnetism of the Oligocene and Miocene Lincoln Creek and Astoria formations, Knappton, Washington. Natural History Museum of Los Angeles County Science Series 41: 63-72.

Rouse, G.W., S.K. Goffredi, S.B. Johnson, and R.C. Vrijenhoek. 2011. Not whale-fall specialists, Osedax worms also consume fishbones. Biology Letters 7: 736-739.

Rouse, G.W., S.K. Goffredi, and R.C. Vrijenhoek. 2004. Osedax: Bone-eating marine worms with dwarf males. Science 305: 668-671.

Snavely, P.D.J., A.R. Niem, N.S. MacLeod, J.E. Pearl, and W.W. Rau. 1980. Makah Formation-A deep-marginal-basin sequence of late Eocene and Oligocene age in the northwestern Olympic Peninsula, Washington. U.S. Geological Survey Professional Paper 1162: 1-28.

Squires, R.L., and J.L. Goedert. 1994. A new species of the volutid gastropod Fulgoraria (Musashia) from the Oligocene of Washington. The Veliger 37: 400-409.

Vrijenhoek, R.C., P. Collins, and C.L. Van Dover. 2008. Bone-eating marine worms: Habitat specialists or generalists? Proceedings of the Royal Society B 275: 1963-1964.

Vrijenhoek, R.C., S.B. Johnson, and G.W. Rouse. 2009. A remarkable diversity of boneworms (Osedax; Siboglinidae, Annelida). BMC Biology 7: 74. 